\title{
Morphological characteristics of wild and cultivated Ganoderma subincrustatum from Sonora, Mexico
}

\author{
Características morfológicas de Ganoderma subincrustatum \\ silvestre y cultivada de Sonora, México
}

\author{
Damian López-Peña ${ }^{1}$, Crystal Samaniego-Rubiano ${ }^{1}$, Idaly Morales-Estrada ${ }^{1}$, Aldo Gutiérrez ${ }^{1}$, Rigoberto \\ Gaitán-Hernández², Martín Esqueda ${ }^{1}$ \\ ${ }^{1}$ Centro de Investigación en Alimentación y Desarrollo, A.C. Carretera Gustavo Enrique Astiazarán Rosas 46, La Victoria. C.P. 83304 \\ Hermosillo, Sonora, México. \\ ${ }^{2}$ Instituto de Ecología A.C., Carretera antigua a Coatepec 351, El Haya. C.P. 91070 Xalapa, Veracruz, México.
}

\begin{abstract}
RESUMEN
Antecedentes: Ganoderma es un género complejo con alta variabilidad morfológica. Ganoderma subincrustatum es una especie parásita y saprobia común y su circunscripción es dudosa para algunos autores. El objetivo de este trabajo fue analizar la variabilidad morfológica de G. subincrustatum silvestre y cultivada.

Métodos: La cepa de Ganoderma subincrustatum se aisló de una huerta de durazno en La Costa de Hermosillo, Sonora. La cepa se cultivó sobre residuos de poda de vid bajo dos condiciones de iluminación baja y alta. Los basidiomas silvestres y cultivados se caracterizaron y compararon macro y microscópicamente.

Resultados y conclusiones: Ganoderma subincrustatum se registra por primera vez para la micobiota Sonorense. La forma, tamaño y color entre basidiomas silvestres y cultivados con iluminación baja y alta fueron diferentes; esta última causó forma de asta de los cuerpos fructíferos. Los especímenes silvestres y cultivados mostraron el mismo tipo de contexto, forma similar de células de la cutícula y basidiosporas, pero basidiosporas más largas en los silvestres.

Palabras clave: taxonomía, circunscripción, tipo de contexto, células de la cutícula
\end{abstract}

\section{ABSTRACT}

Background: Ganoderma is a complex genus with high morphological variability. Ganoderma subincrustatum is a common parasite and saprophytic species, and its circumscription is doubtful for some authors. The aim of this study was to analyze the morphological variability of wild and cultivated specimens of $G$. subincrustatum.

Methods: Ganoderma subincrustatum strain was isolated from a peach orchard in La Costa de Hermosillo, Sonora. The strain was cultivated on vineyard pruning wastes under low and high illumination. Wild and cultivated basidiomata were macro and microscopically characterized and compared.

Results and conclusions: Ganoderma subincrustatum was recorded for the first time from Sonoran mycobiota. Basidiomata color, size and shape were different between wild and cultivated under low and high illumination. High lux condition caused antler shape fruiting bodies. Wild and cultivated specimens showed the same type of context, similar shape of pileipellis cells and basidiospores, but basidiospores were larger in wild specimens.

Keywords: taxonomy, circumscription, context type, pileipellis cells

\section{ARTICLE HISTORY}

Received 14/07/ 2018 / Accepted 11/03/2019

Published on line 26/03/2019

\section{INTRODUCTION}

Ganoderma P. Karst. (Polyporales: Ganodermataceae) is a genus with cosmopolitan distribution, registered from tropical, temperate, agricultural and desert-like areas (Gottlieb and Wright 1999; Torres-Torres et al., 2012; López-Peña et al., 2016). Morphological plasticity makes Ganoderma one of the most complex genus

\section{CORRESPONDING AUTOR}

Martín Esqueda, esqueda@ciad.mx ORCID: 0000-0003-0132-1810

in Polyporales; a sign of this are the 290 published names, many of these are considered synonyms (Ryvarden, 2000). Therefore, different molecular markers for species delimitation have been assessed (Douanla-Meli and Langer, 2009; Wang et al., 2012).

The taxonomy of Ganoderma is usually based on macro and micromorphological characters, being the most important shape and size of basidiospores and pilei- 
pellis cells (Steyaert, 1972; Gottlieb and Wright, 1999; Ryvarden, 2000). Recently, resinous incrustations and context type were used to discriminate some species, since they also are constant characters (Torres-Torres et al., 2012). A not fully homogeneous context with resinous bands and incrustations are characteristics of $\mathrm{Ga}$ noderma subincrustatum Murrill, a species recorded from Argentina, Jamaica, and Mexico (Torres-Torres et al., 2015).

Most of the farm products from La Costa de Hermosillo are produced to exportation purposes, and annually big losses are caused by Ganoderma infections in peach orchards. G. subincrustatum is a facultative parasite or saprobic species recorded mainly from tropical and subtropical areas, even in Pinus-Quercus forest (Torres-Torres et al., 2015). There are few works based on fruiting bodies development under controlled conditions for biotechnological purposes such as improving the production of medicinal mushrooms (Islam et al., 2011; Sudheer et al., 2018).

To our knowledge, there are no studies on morphological characterization to determine the variability of main taxonomic characters between wild and cultivated $\mathrm{Ga}$ noderma species. Due to this fact, the aim of this study was to compare the morphological characteristics of wild and cultivated specimens of a G. subincrustatum strain, and to evaluate the effect of culture conditions, mainly light intensity, on fruiting bodies development in order to investigate if taxonomic characters remain constant among them.

\section{MATERIALS AND METHODS}

\section{Basidiomata and strain}

Basidiomata were collected on a living Prunus persica (L.) Batsch tree in a peach orchard at La Costa de Hermosillo, Sonora, Mexico, September 7, 2012, and deposited in the Mushroom Collection of Universidad Estatal de Sonora under voucher UES (10500). On that date, temperature varied from 24 to $37^{\circ} \mathrm{C}$, and relative humidity from 24 to $89 \%$ (Weather Underground, 2016). This orchard is under constant watering; thus, moisture in the environment remains high. Sections of hymenophore were placed in Petri dishes with malt extract agar (MEA), supplemented with chloramphenicol $\left(0.5 \mathrm{gL}^{-1}\right)$ and benomyl $\left(22 \mathrm{mgL}^{-1}\right)$. After mycelium development, sections were transferred to MEA without supplements. Mycelia-samples from this second cultu- re were examined to find clamp connections (Largent et al., 1977) with an Olympus BX51 microscope. Abundant clamps were observed in the isolated mycelia, which serve as indicative of good isolation, because clamps are basidiomycete's specific structures. Likewise, cultivated basidiomata were harvested for morphological characterization and deposited under vouchers UES (10501, 10502, 10503, 10504). Ganoderma subincrustatum strain was maintained on MEA Petri dishes.

\section{Inoculum and cultivation conditions}

Inoculum preparation was carried out using wheat grain. Grain was soaked for $24 \mathrm{~h}$ in distilled water to reach $60 \%$ humidity, later sterilized at $121{ }^{\circ} \mathrm{C}$ for $1.5 \mathrm{~h}$. After temperature was down, wheat grain was inoculated with portions of the MEA culture. Vineyard pruning wood chips unsupplemented (2-3 cm in length) were hydrated for $12 \mathrm{~h}$, drained and sterilized in polypropylene bags (700 $\mathrm{g}$ of wet substrate per bag) for 1.5 $\mathrm{h}$ at $121^{\circ} \mathrm{C}$. The bags were inoculated with $5 \%(\mathrm{w} / \mathrm{w})$ of wheat grain spawn and incubated in darkness at $25 \pm 1{ }^{\circ} \mathrm{C}$ until substrates were fully colonized (15-17 d). Basidiomata development was performed under two conditions, one of them was maintained at $25 \pm 1^{\circ} \mathrm{C}$, $85-90 \%$ of relative humidity $(\mathrm{RH})$ and 350 lux (low light condition). The other was $27 \pm 1{ }^{\circ} \mathrm{C}, 90-100 \% \mathrm{RH}$ and 3500-4000 lux (high light condition), photoperiod for both treatments was $12 \mathrm{~h}$ (Stamets, 2000) using coldlight fluorescent lamps and $\mathrm{CO}_{2}$ was maintained at 500600 ppm, because is an important factor for fruiting bodies development. Basidiomata were harvest when growth stopped, with two developmental shapes: antler (3500-4000 lux treatment), and flabelliform fully developed pileus (350 lux treatment) to study macro and microscopic features (Gottlieb and Wright, 1999; Torres-Torres and Guzmán-Dávalos, 2012).

\section{Morphological characterization}

For morphological characterization, thin sections of basidiomata were mounted in $10 \% \mathrm{KOH}$ and analyzed using an Olympus BX51, with an Infinity Analyze 2 integrated camera for microscopic descriptions. Basidiospore shape was expressed according to $\mathrm{Q}$ ratio (length/width) of at least 20 randomly selected spores (Largent et al., 1977). Color descriptions were made according to Kornerup and Wanscher (1978). Because G. subincrustatum is a first record from Sonora, a full description of wild basidiomata is presented. 


\section{RESULTS}

Wild basidiomata description

Basidiomata 178-270 × 117-124 × 22-70 mm, substipitate to sessile, dimidiate, fibrous to spongy. Pileus flabelliform, surface glabrous, smooth, slightly dented and corrugated, bright to dull, with semi-concentric furrows, more conspicuous to the margin, cuticle light orange (5A5), reddish-golden (6C7), deep orange (6A8), light brown (6D8), reddish-brown (8E6), dark brown (8F8) to photo brown (9F8), almost black in some zones, with deep yellow (4A8) furrows due to cuticle detaching, covered by a brown (6E8) basidiospores layer; margin sterile, obtuse, smooth, with groove zones, pale yellow (4A3), with yellowish-orange (4A7) zones, greyish yellow (4C7) after contact. Context up to $22 \mathrm{~mm}$ thick, fibrous-spongy, not fully homogenous, with a deep yellow (4A8) band under the cuticle, light orange (5A5) to brown (5F7) toward the tubes, concentrically zonate, with two resinous bands, the upper thickened, both intermittent, 3/4 context length, interrupted near the margin. Tubes up to $14 \mathrm{~mm}$ long, brown (5E8), orange white (5A2) towards the pores surface, unstratified. Pores 3-5 per mm, 133-171 $\mu \mathrm{m}$ diam, pale yellow (4A3), greyish-yellow (4C7) after contact, angular to rounded, with irregular edge. Stipe 50-75 $\times$ 29-52 mm, lateral, smooth, shiny to dull, photo brown (9F8), flattened to cylindrical, solid, fibrous to spongy, concentrically zonate.

Trimitic hyphal system. Generative hyphae 1.6-7.2 $\mu \mathrm{m}$ diam, septate, fibulate, hyaline to pale yellow, difficult to observe, generally collapsed; skeletal hyphae arboriform to non-branched, 1.6-7.2 $\mu \mathrm{m}$ diam, solid to thick-walled, light brown; connective hyphae branched, 1.6-3.2 $\mathrm{mm}$ diam, thick-walled, hyaline to pale yellow. Pileipellis as a crustohymeniderm, cells 31.2$90.4 \times 8-12 \mu \mathrm{m}$, narrow clavate to clavate, commonly with one to three protuberance or branches, solid to tick walled, sometimes multistratified, pale yellow to deep yellow. Basidiospores (8-)9.6-11.2(-12.8) × 5.6-8 $\mu \mathrm{m}, \mathrm{Q}=1.49-1.64$, ellipsoids to oblong, apex truncate, with apical germ pore, exosporium with subfree to partially anastomosed interwalled pillars, reddish-brown.

\section{Wild versus cultivated basidiomata}

Basidiomata variability in size, color and shape were observed among wild and cultivated specimens, also among those cultivated under different illumination treatments (Table 1, Figure 1). Context type remained similar between wild and cultivated basidiomata, even those harvested with antler-like shape, which remains as a significant character in G. subincrustatum. Shape of pileipellis cells and basidiospores seems to be a constant character in $G$. subincrustatum. In both cases, cells were clavate, with two or three lateral or apical branches or protuberances, light to deep yellow, some of them with apical incrustations.

Slight basidiospores variability between wild and cultivated specimens was observed. Wild basidiomata showed larger basidiospores, mostly ellipsoids, some oblong, while cultivated basidiomata mainly ellipsoids basidiospores, some broadly ellipsoids; all of them with subfree to partially anastomosed interwalled pillars.

TABLE 1. Morphological variability between wild and cultivated basidiomata of Ganoderma subincrustatum

\begin{tabular}{|c|c|c|c|}
\hline & WILD & $\begin{array}{l}\text { Cultivated } \\
350 \text { Lux }\end{array}$ & $\begin{array}{l}\text { Cultivated } \\
3500-4000 \text { Lux }\end{array}$ \\
\hline Basidiomata size & $178-270 \times 117-124 \times 22-70 \mathrm{~mm}$ & $59-84 \times 39-75 \times 6-19 \mathrm{~mm}$ & $55-123 \times 11-29 \times 9-17 \mathrm{~mm}$ \\
\hline Pileus shape & Flabelliform & Flabelliform & Antler \\
\hline Context & $\begin{array}{l}\text { up to } 20 \mathrm{~mm} \text { thick } \\
2 \text { resinous bands }\end{array}$ & $\begin{array}{l}\text { up to } 13 \mathrm{~mm} \text { thick } \\
2 \text { resinous bands }\end{array}$ & $\begin{array}{l}\text { up to } 4 \text { mm thick } \\
1-2 \text { resinous band }\end{array}$ \\
\hline Hymenophore & Tubes up to $14 \mathrm{~mm}$ long & Tubes up to $8 \mathrm{~mm}$ long & undeveloped \\
\hline Pileipellis cells & $\begin{array}{l}31.2-90.4 \times 8-12 \mu \mathrm{m} \\
\text { sometimes multistratified, with } \\
\text { protuberances }\end{array}$ & $\begin{array}{l}42.3-58.8 \times 5.3-9.6 \mu \mathrm{m} \text { with apical } \\
\text { incrustations and protuberances }\end{array}$ & $\begin{array}{c}29-52.1 \times 7.1-9.2 \mu \mathrm{m} \\
\text { with apical incrustations and protu- } \\
\text { berances }\end{array}$ \\
\hline Basidiospores & $\begin{array}{c}\text { 9.6-11.2 } \times 5.6-8 \mu \mathrm{m} ; \mathrm{Q}=1.49-1.64 \\
\text { ellipsoid to oblong }\end{array}$ & $\begin{array}{c}\text { 7.7-9.9 } \times 5.7-7.7 \mu \mathrm{m} ; \mathrm{Q}=1.21- \\
1.47 \text { ellipsoid }\end{array}$ & undeveloped \\
\hline
\end{tabular}




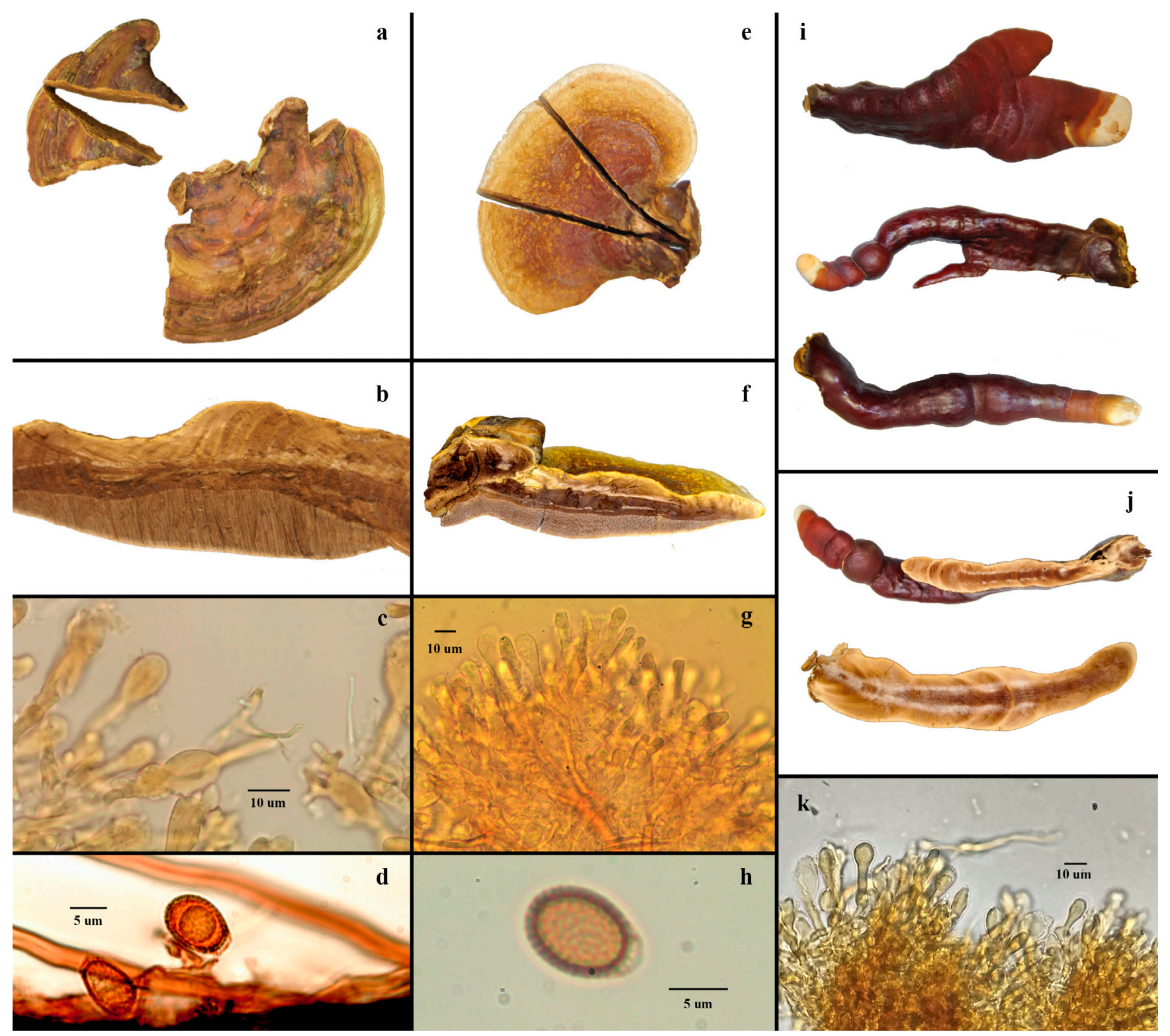

FIGURE 1. Morphological characteristics of Ganoderma subincrustatum. a-d: wild specimen. a: basidiome. b: context. c: cuticle elements. d: basidiospores. e-h: cultivated specimens under 350 lux. e: basidiomata. f: context. g: cuticle elements. h: basidiospore. i-k: cultivated specimens under 3500-4000 lux. i: basidiomata. j: context. k: cuticle elements.

\section{DISCUSSION}

Wild basidiomata presented a larger size than cultivated, which could be attributed to different environmental conditions. Some specimens under high light conditions were developed with antler-like shape, others with long stipe, and some tended to develop flabelliform pileus with hymenophore (Figure 1i). Stamets (2000) mentioned that under low light conditions, stipe elongation becomes slow and the mycelium enters into the pilei development period in G. lucidum, thus longer stipes in cultiva- ted specimens could be attributed to illumination condition.

According with Torres-Torres et al. (2015), G. subincrustatum presents a perennial growth, but Gottlieb and Wright (1999) did not mention that character. In this study all basidiomata were harvested in their first developmental stage, even the wild specimen. Bazzalo and Wright (1982), and Ryvarden (2000) considered $G$. subincrustatum synonym under $G$. resinaceum, but Gottlieb and Wright (1999) contemplated it as independent species, with pileipellis cells of $33-45 \times 8-10 \mu \mathrm{m}$, and basidiospores of (9-)10-12(-13) 
× 6-9 $\mu \mathrm{m}$. On the other hand, Torres-Torres et al. (2015) recognized $G$. subincrustatum as independent species, and report pilleipelis cells of 32-80(96) $\times$ 5.5-14.5 $\mu \mathrm{m}$, and basidiospores of 9.6-12.4 $\times$ 7.2-8.4 $\mu \mathrm{m}$.

In the present work, we recorded smaller basidiospores than those characterized by Torres-Torres et al. (2015) for this species, which probably can be attributed to environmental conditions; however, the shape remains equal. Steyaert (1975) observed a positive influence of altitude or latitude on mean lengths of basidiospores. An increase in temperature seems to depress basidiospore size. Temperature varies in the same direction whether in altitude or latitude and would consequently be the ruling factor for mean basidiospores size.

Islam et al. (2011) worked with several light intensity (0-850 lux) in G. lucidum cultivation and development and reported the largest pileus diameter at 570 lux and the smallest at 0 lux. Sudheer et al. (2018) evaluated the $\mathrm{CO}_{2}$ concentration and presence or absence of light (742 lux) on Ganoderma fruiting bodies development. They observed antler-like and spider-like fruiting bodies, depending on the presence or absence of light, respectively; both treatments with high $\mathrm{CO}_{2}$ concentration. None of these studies evaluated light intensities higher than 850 lux. In our study, light intensity of 3500-4000 lux provoked antler-like fruiting bodies in $\mathrm{G}$. subincrustatum. Although our treatments had a slight difference in temperature and $\mathrm{RH}$, nevertheless, both were in the recommended range for production of Ganoderma lucidum basidiomata (Stamets, 2000; Lakshmi, 2013); thus, differences in basidiomata shape could be attributed to light intensity.

In summary, this study contributes to the circumscription of $G$. subincrustatum. Due to the intrinsic species variability recorded for Ganoderma spp. worldwide, it is necessary to continue working on its taxonomy, analyzing molecularly more species to understand the phylogeny of this genus, and to demonstrate G. subincrustatum is a real independent species.

\section{REFERENCES}

Bazzalo, M.E., J.E. Wright, 1982. Survey of the Argentine species of the Ganoderma lucidum complex. Mycotaxon 16: 293-325.

Douanla-Meli, C., E. Larger, 2009. Ganoderma carocalcareus sp. nov., with crumbly-friable context parasite to saprobe on An- thocleista nobilis and its phylogenetic relationship in G. resinaceum group. Mycological Progress 8: 145-155. https://doi. org/10.1007/s11557-009-0586-4

Gottlieb, A.M., J.E. Wright, 1999. Taxonomy of Ganoderma from southern South America: subgenus Ganoderma. Mycological Research 103: 661-673. https://doi.org/10.1017/ S0953756298007941

Islam, M., N.C. Sarker, S.K. Biswas, R. Amin, 2011. Effect of light intensity and its management practices on yield of Ganoderma lucidum. Bangladesh Journal Mushroom 5: 17-22.

Kornerup, A., J.H. Wanscher, 1978. Methuen handbook of color. London: Eyre Methuen.

Lakshmi, S.S., 2013. In vitro utilization of seafood processing wastes for cultivation of the medicinal mushroom (Ganoderma lucidum) using agro-industrial waste. Asian Journal of Pharmaceutical and Clinical Research 6: 51-54.

Largent, D.L., D. Johnson, R. Watling, 1977. How to Identify Mushrooms to Genus III: Microscopic Features. Mad River Press, Eureka.

López-Peña, D., A. Gutiérrez, E. Hernández-Navarro, R. Valenzuela, M. Esqueda, 2016. Diversidad y distribución de Ganoderma (Polyporales: Ganodermataceae) en Sonora, México. Botanical Sciences 94: 431-439. https://doi.org/10.17129/botsci.463

Ryvarden, L., 2000. Studies in Neotropical Polypores 2: A preliminary key to Neotropical species of Ganoderma with a laccate pileus. Mycologia 92: 180-191. https://doi.org/10.2307/3761462

Stamets, P., 2000. Growing gourmet and medicinal mushrooms. Ten Speed Press, Berkeley.

Steyaert, R.L., 1972. Species of Ganoderma and related genera mainly of Bogor and Leiden herbaria. Persoonia 7: 55-118.

Steyaert, R.L., 1975. The concept and circumscriptions of Ganoderma tornatum. Transactions of the British Mycological Society 65: 451-467.

Sudheer, S., Z. Taha, S. Manickam, A. Ali, P.G. Chen, 2018. Development of antler-type fruiting bodies of Ganoderma lucidum and determination of its biochemical properties. Fungal Biology. https://doi.org/10.1016/j.funbio.2018.01.007

Torres-Torres, M.G., L. Guzmán-Dávalos, 2012. The morphology of Ganoderma species with a laccate surface. Mycotaxon 119: 201 216. https://doi.org/10.5248/119.201

Torres-Torres, M.G., L. Guzmán-Dávalos, A.M. Gugliotta, 2012. Ganoderma in Brazil: known species and new records. Mycotaxon 121: 93-132. https://doi.org/10.5248/121.93

Torres-Torres, M.G., L. Ryvarden, L. Guzmán-Dávalos, 2015. Ganoderma subgenus Ganoderma in Mexico. Revista Mexicana de Micología 41: 27-45.

Wang, X.C., R.J. Xi, Y. Li, D.M. Wang, Y.J. Yao, 2012. The species identity of the widely cultivated Ganoderma, 'G. lucidum' (Lingzhi), in China. PLoS One 7: e40857. https://doi.org/10.1371/ journal.pone.0040857

Weather Underground, 2016. Find your hyper local weather. The Weather Company, LLC http://www.wunderground.com (accessed 25 July 2016). 